\title{
Religiosity and Internal Developmental Assets amongst Malay Adolescents in Malaysia
}

\author{
Siti Nor Yaacob ${ }^{1}$, Tan Soon Aun ${ }^{2}$, Siti Marnizah Binti Abdul Rahim ${ }^{3}$, Muslihah Hasbullah ${ }^{3}$, Rumaya Juhari ${ }^{1} \&$ \\ Rozumah Baharudin ${ }^{1}$ \\ ${ }^{1}$ Family, Adolescent and Child Research Center of Excellence (FACE), Faculty of Human Ecology, Universiti \\ Putra Malaysia, Malaysia \\ ${ }^{2}$ Department of Psychology and Counselling, Faculty of Arts and Social Science, Universiti Tunku Abdul \\ Rahman, Malaysia \\ ${ }^{3}$ Department of Human Development and Family Studies, Faculty of Human Ecology, Universiti Putra Malaysia, \\ Malaysia \\ Correspondence: Siti Nor Yaacob, Family, Adolescent and Child Research Center of Excellence (FACE), \\ Faculty of Human Ecology, Universiti Putra Malaysia, Malaysia. E-mail: sitinor@upm.edu.my
}

\author{
Received: December 10, 2014 Accepted: January 19, 2015 Online Published: April 30, 2015 \\ doi:10.5539/ass.v11n12p181 URL: http://dx.doi.org/10.5539/ass.v11n12p181
}

\begin{abstract}
This study aimed to examine the relationship between religiosity and internal developmental assets amongst Malay adolescents in Malaysia. A total of 737 school-going Malay adolescents were recruited by using multistage cluster sampling method from four states (Selangor, Kedah, Kelantan and Johor) of Peninsular Malaysia. The results of the study indicated that Malay adolescents have good Islamic knowledge and practices, and in general they have good internal developmental assets. Both Islamic worldview (knowledge) and personality (practices) were found to have positive significant relationships with overall internal developmental assets and its specific domains. Precisely, Islamic personality denoted to be the strongest predictor in determining Malay adolescents' internal developmental assets. Religious-based intervention should be emphasized to enhance adolescents' internal developmental assets.
\end{abstract}

Keywords: internal developmental assets, Islamic personality, Islamic worldview, Malay adolescents, religiosity

\section{Introduction}

During adolescence, religiosity plays a vital role in contributing to developmental outcomes. Religiosity development is a contextual process which influences adolescents through involvement of peer, family members and also religious organization (French, Purwono, \& Triwahyuni, 2011; Petts, 2009; Regnerus, \& Smith, 2004; Wilcox, Chaves, \& Franz, 2004). Studies in Western countries indicated that religious institutions, such as church provide appropriate parenting skills through cultivation of belief and religious practices; family can encourage religious participation and socialization among adolescents; while peer might affect religious practices and attitudes among adolescents (Petts, 2009; Regnerus et al., 2004; Schwartz et al., 2006; Wilcox et al., 2004). Religious life that occurs within adolescents' social circle may have positive impact on their developmental outcomes (Ortega \& Krauss, 2013).

Religiosity assumed as a positive trait may help adolescents reach a level of transcendence in which one is able to think and show concern for others and this ability is indispensable for one to advance in larger society (Lerner, 2004). Empirical studies in social psychology reported that religiosity contributed to positive developmental outcomes in aspects of cognition, emotion and behaviour among adolescents (Argyle, 2002; Ortega \& Krauss, 2013). Religiosity can be potential forces that affect human nature, motivation, personality development, the self, the unconscious, psychological adjustment and the society (Smither \& Khorsandi, 2009). Adolescence is a developmental stage where adolescents explore the larger social world and will be exposed to risk factors (Nebbit, 2012). In order to achieve a healthy adulthood, adolescents need to overcome obstacles and negative life events with their ability and capability along the developmental transition. For instance, adolescents who are active in social and school life might need to solve peer relationship problem or overcome academic stress. Previous studies reported that religiosity can foster prosocial behavior and moral identity; in turn promote 
positive development outcomes among adolescents (Hardy \& Carlo, 2005; Hardy \& Walker, 2012; Walker \& Reimer, 2008). Religiosity contributed to positive development outcomes that include academic achievement, resilience, restrains from anxiety and perceived social support (Milot \& Ludden, 2009; Pardini et al., 2000). In addition, studies in Western and Middle East countries provided evidence that religious adolescents tend to experience greater levels of happiness, life satisfaction, mental and physical health, psychological well-being and psychosocial health (Abdel-Khalek, 2009; Ball, Armstead, \& Austin, 2003; Yonker, Schnabelrauch, \& DeHaan, 2012).

During the development process, adolescents need to possess some characteristics which can assist them to develop healthy development. Developmental assets are characteristics that may help adolescents to be healthy, responsible, accountable, caring, and capable of choosing and making decision (Nor Ba'yah et al., 2012). Developmental assets provide adolescents the skills and values they need to achieve aims applauded by the mainstream society (Search Institute, 2008). An increase in developmental assets may trigger thriving behavior and reduced risky behavior engagement among adolescents (Search Institute, 2004). Internal developmental assets represents the characteristics within individuals which included commitment to learning, positive values, social competency and positive identity; and these characteristics have been associated with better thriving behavior, responsibilities, healthy behavior, resisting negative peer pressure, optimism and self-esteem (Search Institute, 2005). With internal assets, adolescents can motivate themselves to obtain positive development outcomes. Adolescents who possess internal developmental assets are able to thrive and contribute to society (Learner, 2004). Occupying these developmental assets, adolescents will be empowered and encouraged to promote healthy development along the adolescence period.

Religiosity as positive forces might be one of the predictor for internal developmental assets. Cultivation of internal developmental assets appears to be important in order to nurture a group of healthy adolescents. Through integration of religion-based belief, values, and morals in adolescents' worldview and identity (Annalakshmi \& Abeer, 2011; King, 2003), adolescents can foster better internal assets. Prior studies indicated that religiosity is positively related to adolescents' internal developmental outcomes, such as, social competence, self-esteem and adjustment (Sallquist, Eisenberg, French, Purwono, \& Suryanti, 2010). Religiosity development that promotes internal assets may provide guidelines for adolescents to develop personal growth. Adolescents who hold positive view and religious belief may be encouraged to behave in certain way, thus they might be socially compliance. Prior study found that religiosity that contributed to self-esteem was positively associated with adjustment (French, Eisenberg, Vaughan, Purwono, \& Suryanti, 2008). Adolescents who perceived social support from religious participation may be less likely to experience loneliness and consequently enhance their sense of belonging to society. Religiousness which promotes the concept of prosocial and empathy (Furrow, King, \& White, 2004) may assist adolescents to succeed in psychosocial development. Prior studies found that religion provides social identity and thus enhances well-being development (Greenfield \& Marks, 2007). Therefore, religiosity may influence internal assets which promote healthy development among adolescents. In addition, demographic factors such as gender had also been shown to relate to adolescent's developmental assets. In general, females tend to have more developmental assets than males (Benson, Scales, Leffert, \& Roehlkepartain, 1999).

Past research argues that religion is one of the contributing factors in adolescents' developmental outcomes, such as internal developmental assets. However, similar studies among Malay adolescents in Malaysia are scarce. Therefore, the current study aimed to determine the relationship between religiosity and internal developmental assets among Malay adolescents. In addition, this study also examined gender difference in levels of religiosity and internal developmental assets. This study addressed to what extent the nature of relationships between religiosity and internal developmental assets established in other cultures is generalizable to Malay adolescents in Malaysia.

\section{Research Methodology}

\subsection{Sample and Sampling Technique}

A total of 737 secondary school adolescents, identified from four states (Selangor, Kedah, Kelantan, and Johor) of Peninsular Malaysia participated in this study. This study employed multistage cluster sampling method with Probability Proportional to Size (PPS) sampling technique since PPS provides equal chance for everyone in the population to be selected as participant in the study. The participants were male $(41.9 \%)$ and female $(58.1 \%)$ adolescents aged between 13 to 17 years old (Mean= 14.87) from 25 urban $(64 \%)$ and rural $(36 \%)$ secondary schools. Data were collected by using self-administered questionnaire. 


\subsection{Data Collection Procedure}

Data were collected by trained enumerators and the questionnaires were administered in the classrooms setting. Respondents were requested to fill in the consent form and informed that their information will be confidential. Permission to conduct the study was obtained from the Ministry of Education, Malaysia; Department of Education from each state, and headmaster of each selected schools. The questionnaires were administered in Malay Language. The instruments which are originally in English language were translated using back-to-back translation. Ethical clearance was approved by the Ethic Committee for Research involving Human Subjects, University Putra Malaysia.

\subsection{Measures}

Internal Developmental Assets. Adolescent internal developmental asset was assessed using Developmental Assets Profile (DAP) (Search Institute, 2005). This scale has two sub-domains: External Assets and Internal Assets. DAP can also be categorized into five contexts which are personal context, social context, family context, school context and community context. Items in the scale were responded with a four points scale ranging from $0=$ Not at all or rarely to $3=$ Extremely or almost always. The Cronbach alpha for overall developmental assets (.93), external assets (.88), and internal assets (.90) indicated that DAP has high reliability. Higher score on the DAP showed the higher presence of the both internal and external assets. Individual with higher assets is often described as having high resiliency, high thriving behavior, and low tendency to engage in risk-taking behavior (Search Institute, 2005).

Religiosity. Respondent's religiosity was assessed using Muslim Religiosity Personality Inventory (MRPI) (Krauss et al., 2006). MRPI was developed to reflect the tawhidic (divine unity) worldview of the Islamic faith and the manifestation of one's worldview in the righteous works. MRPI has two domains which are Islamic worldview and Religiosity personality. Islamic worldview assesses individuals' Islamic creed (aqidah) as laid down by Quran and Sunnah (way). Islamic worldview has two sub-dimensions that are Worldly and Spiritual. Worldly measures the level of belief or understanding of the congruence of Islam with worldly life (e.g., All Islamic laws can be modified to fulfill contemporary needs). The spiritual assesses individuals' belief or understanding of God's relations with creation (e.g.; Worldly life cannot be separated from the afterlife) Religious personality assesses respondent's personal manifestation (behaviour, motivation and attitude) of the Islamic teachings and commands and it has two sub-dimensions which are rituals and mu'amalat (prosocial behaviors). Ritual is related to the formal worship that reflects one's direct relationship with God (e.g., I encourage my family members to follow the teachings (sunnah) of Rasulullah). Mu'amalat or prosocial behaviors refers to the religiously-guided behaviour of an individual towards family, fellow human beings and other God's creation (e.g., I do not expose the shortcomings of others). The present study used revised MRPI Scales that contains 47 items. The response for items in the scale is based on the six point scale from $1=$ strongly disagree to $6=$ strongly agree. Total score was computed with high score displays high individual religiosity (Krauss, 2011). Cronbach alpha for both MRPI sub-domains are .66 (Islamic Worldview) and .92 (Religious Personality), while the cronbach alpha for the four sub-scales are: Worldly $=.83$; Spiritual $=.67$; Ritual $=.90$ and Mu'amalat $=.83$.

\subsection{Data Analyses}

Data of the study were analyzed by using Statistical Package for Social Science (SPSS). Descriptive statistics, t-test, Pearson correlation, and multiple regression analysis were conducted to address the objectives of the study.

\section{Results}

\subsection{Descriptive Analysis}

Table 1 presents the distribution of adolescents' score on religiosity variables and adolescents' internal developmental assets. The category for religiosity and developmental assets were developed based on a cut-off point suggested by the authors. More than half of the adolescents scored moderate to high on all the religiosity variables (religiosity worldview, worldly, spiritual, religiosity personality, ritual and mu'amalat). In term of internal developmental assets, adolescent obtained good and fair scores (83.6\%) for total internal developmental assets. More specifically, above $75 \%$ of adolescents scored good and fair in all the sub-scales (commitment to learning, positive values, social competency and positive identity) for internal assets.

\subsection{Bivariate Analysis}

In relation to total internal developmental assets, significant relationships were found between religiosity worldview $(r=.204, p<.000)$, worldly Islamic worldview $(r=.125, p<.000)$, spiritual Islamic worldview 
$(r=.216, p<.000)$, religiosity personality $(r=.638, p<.000)$, ritual religious personality $(r=.533, p<.000)$ and mu'amalat religious personality $(r=.617, p<.000)$ with internal developmental assets (Table 2). Results showed that adolescents who have positive worldly and spiritual Islamic worldview and good ritual and mu'amalat religious personality had better total internal developmental assets.

In term of specific dimension of internal developmental assets, religiosity and its sub-scales had significant positive relationship with all the sub-dimensions of adolescents' internal developmental assets (commitment to learning, positive values, social competency and positive identity). The findings of the study also revealed that adolescents who internalize and practice Islamic values tend to have high commitment to learning, positive values, good social competency and positive identity.

Table 1. Distribution of respondents on independent and dependent variables $(\mathrm{N}=737)$

\begin{tabular}{|c|c|c|c|c|c|}
\hline Variable & n (\%) & Mean & S.D & Min. & Max. \\
\hline \multicolumn{6}{|l|}{ Religiosity } \\
\hline Religiosity worldview & & 4.50 & 0.48 & 2.99 & 5.70 \\
\hline Low & $41(5.6)$ & & & & \\
\hline Medium & $414(56.2)$ & & & & \\
\hline High & $282(38.3)$ & & & & \\
\hline Worldview-Worldly & & 4.26 & 0.59 & 2.23 & 5.54 \\
\hline Low & $63(8.5)$ & & & & \\
\hline Medium & $509(69.1)$ & & & & \\
\hline High & $165(22.4)$ & & & & \\
\hline Worldview-Spiritual & & 4.75 & 0.68 & 2.14 & 6 \\
\hline Low & $56(7.6)$ & & & & \\
\hline Medium & $307(41.7)$ & & & & \\
\hline High & $374(50.7)$ & & & & \\
\hline Religiosity Personality & & 4.40 & 0.71 & 2.30 & 6 \\
\hline Low & $26(3.5)$ & & & & \\
\hline Medium & $213(28.9)$ & & & & \\
\hline High & $498(67.6)$ & & & & \\
\hline Personality-Ritual & & 4.18 & 0.83 & 2 & 6 \\
\hline Low & $112(15.2)$ & & & & \\
\hline Medium & $329(44.6)$ & & & & \\
\hline High & $296(40.2)$ & & & & \\
\hline Personality-Muamalat & & 4.62 & 0.74 & 2.07 & 6 \\
\hline Low & $7(0.9)$ & & & & \\
\hline Medium & $139(18.9)$ & & & & \\
\hline High & $591(80.2)$ & & & & \\
\hline Internal Assets & & 19.54 & 3.81 & 8.46 & 29.27 \\
\hline Low & $85(11.5)$ & & & & \\
\hline Good & $396(53.7)$ & & & & \\
\hline Fair & $220(29.9)$ & & & & \\
\hline Excellent & $36(4.9)$ & & & & \\
\hline Internal-Commitment to learning & & 19.31 & 4.65 & 5.71 & 30 \\
\hline Low & $132(17.9)$ & & & & \\
\hline Good & $325(44.1)$ & & & & \\
\hline Fair & $227(30.8)$ & & & & \\
\hline Excellent & $53(7.2)$ & & & & \\
\hline Internal- Positive values & & 19.41 & 4.18 & 6.36 & 30 \\
\hline Low & $108(14.7)$ & & & & \\
\hline Good & $380(51.6)$ & & & & \\
\hline Fair & $203(27.5)$ & & & & \\
\hline Excellent & $46(6.2)$ & & & & \\
\hline Internal - Social Competency & & 19.75 & 4.45 & 7.50 & 30 \\
\hline Low & $96(13.0)$ & & & & \\
\hline Good & $322(43.7)$ & & & & \\
\hline Fair & $245(33.2)$ & & & & \\
\hline Excellent & $74(10.0)$ & & & & \\
\hline Internal - Positive identity & & 19.69 & 4.70 & 6.67 & 30 \\
\hline Low & $93(12.6)$ & & & & \\
\hline Good & $340(46.1)$ & & & & \\
\hline Fair & $231(31.3)$ & & & & \\
\hline Excellent & $73(9.9)$ & & & & \\
\hline
\end{tabular}


Table 2. Correlation between religiosity and internal developmental assets $(\mathrm{N}=737)$

\begin{tabular}{lccccc}
\hline \multirow{2}{*}{ Variable } & \multicolumn{5}{c}{ Pearson correlation $(r)$} \\
\cline { 2 - 6 } & $\begin{array}{c}\text { Internal } \\
\text { assets }\end{array}$ & $\begin{array}{c}\text { Commitment to } \\
\text { learning }\end{array}$ & $\begin{array}{c}\text { Positive } \\
\text { values }\end{array}$ & $\begin{array}{c}\text { Social } \\
\text { competency }\end{array}$ & $\begin{array}{c}\text { Positive } \\
\text { identity }\end{array}$ \\
\hline Religiosity & & & & \\
Worldview & $.204^{* * *}$ & $.142^{* * *}$ & $.202^{* * *}$ & $.186^{* * *}$ & $.167^{* * *}$ \\
$\quad$ Worldview-Worldly & $.125^{* * *}$ & $.075^{*}$ & $.120^{* *}$ & $.122^{* *}$ & $.110^{* *}$ \\
$\quad$ Worldview-Spiritual & $.216^{* *}$ & $.169^{* * *}$ & $.218^{* * *}$ & $.184^{* * *}$ & $.165^{* * *}$ \\
Personality & $.638^{* * *}$ & $.578^{* * *}$ & $.617^{* * *}$ & $.526^{* * *}$ & $.451^{* * *}$ \\
$\quad$ Personality-Ritual & $.533^{* * *}$ & $.530^{* * *}$ & $.519^{* * *}$ & $.397^{* * *}$ & $.366^{* * *}$ \\
$\quad$ Personality-Muamalat & $.617^{* * *}$ & $.510^{* * *}$ & $.593^{* * *}$ & $.552^{* * *}$ & $.446^{* * *}$ \\
\hline
\end{tabular}

Note. ${ }^{*} \mathrm{p}<.05 ; * * \mathrm{p}<.01 ; * * * \mathrm{p}<.001$

Table 3 presents respondents' scores for all the main variables examined by gender. For internal developmental assets, female adolescents scored higher in both commitment to learning $(t=-2.972, p<.01)$ and social competency $(\mathrm{t}=-2.085, \mathrm{p}<.05)$ as compared to male adolescents. Precisely, female adolescents showed better commitment in learning (mean=1.97) and more competent in social development (mean=2.00).

The $t$-test results indicated the significant difference between male and female adolescents in their worldly Islamic worldview $(\mathrm{t}=-3.003, \mathrm{p}<.01)$. Specifically, female $(\mathrm{mean}=4.32)$ adolescents tend to have better worldly Islamic worldview as compared to male (mean $=4.18)$ adolescents. Results of the study also denoted that female adolescents (mean $=4.55)$ scored significantly higher than male $(m e a n=4.44)$ adolescents in religions worldview $(\mathrm{t}=-2.889, \mathrm{p}<.01)$. However, the other variables did not show significant differences. In others, male adolescents showed slightly better internal developmental assets, as well as stronger ritual religious personality than female adolescents. In term of spiritual Islamic worldview and mu'amalat religious personality, female presented stronger or better religiosity as compared to male adolescents.

Table 3. Differences in religiosity and internal developmental assets by gender $(\mathrm{N}=737)$

\begin{tabular}{|c|c|c|c|c|}
\hline \multirow{2}{*}{ Variable } & Male & Female & \multirow{2}{*}{$t$} & \multirow{2}{*}{$p$} \\
\hline & \multicolumn{2}{|c|}{ Mean } & & \\
\hline \multicolumn{5}{|l|}{ Developmental Assets } \\
\hline Internal assets & 19.35 & 19.68 & -1.145 & .253 \\
\hline Commitment to learning & 1.87 & 1.97 & $-2.972 * *$ & .003 \\
\hline Positive values & 1.93 & 1.94 & -.577 & .564 \\
\hline Sosial Competency & 1.93 & 2.00 & $-2.085^{*}$ & .037 \\
\hline Positive identity & 2.00 & 1.94 & 1.701 & .089 \\
\hline \multicolumn{5}{|l|}{ Religiosity } \\
\hline Worldview & 4.44 & 4.55 & $-2.889 * *$ & .004 \\
\hline Worldview-Worldly & 4.18 & 4.32 & $-3.003 * *$ & .003 \\
\hline Worldview-Spiritual & 4.70 & 4.78 & -1.519 & .129 \\
\hline Personality & 4.39 & 4.41 & -.412 & .680 \\
\hline Personality-Ritual & 4.21 & 4.16 & .909 & .364 \\
\hline Personality-Mu'amalat & 4.56 & 4.66 & -1.808 & .071 \\
\hline
\end{tabular}

Note. ${ }^{*} \mathrm{p}<.05 ; * * \mathrm{p}<.01$

\subsection{Multivariate Analysis}

The characteristics of adolescents (sex, age and residential area) and subdomains of religiosity were regressed against internal developmental assets. Results in Table 4 showed that religious personality (Beta $=.620, p<.000$ ) appears to be the strongest and the only significant predictor in explaining internal developmental assets among adolescents. Positive regression weights indicated that adolescents with higher level of religious personality reported to have greater internal developmental assets. The adjusted $\mathrm{R}^{2}$ results indicated that personal background and religiosity subdomains elucidated $40.4 \%$ of variance in explaining adolescents' internal developmental assets. 
Table 4. Regression analyses for internal developmental assets $(\mathrm{N}=737)$

\begin{tabular}{lcc}
\hline Variable & \multicolumn{2}{c}{ Internal Assets } \\
\cline { 2 - 3 } & Unstandardized Coefficient B & Standardized Coefficient $\beta$ \\
\hline Personal Background & & .028 \\
Sex $(0=$ Male, 1=Female) & .221 & .043 \\
Age & .107 & .022 \\
Residential Area (0=urban, 1=rural) & .235 & .040 \\
Religiosity & & $.620 * * *$ \\
Worldview & .240 & \\
Personality & .161 & \\
Adjusted $\mathbf{R}^{2}=.404$ & & \\
$\mathbf{F}_{(5,731)}=102.09 * * *$ & & \\
\hline Note. $* * * \mathrm{p}<.001$ & &
\end{tabular}

\section{Discussion}

This study aimed to determine the relationship between religiosity and internal developmental assets among Malay adolescents in Malaysia. Generally, Malay adolescents scored high in all the religiosity variables which are both spiritual and worldly aspects of Islamic worldview as well as Muslim personality dimension of ritual and mu'amalat. They have good level of overall internal developmental assets and its subdomains (commitment to learning, positive values, social competency and positive identity).

The results of the study showed that all the religiosity variables are significantly related to adolescents' internal assets. Adolescents who have high spiritual aspect of Islamic worldview, good personal striving related to Islamic ritual worship and good relations with all other creations tend to have better internal assets. Both spiritual and practical aspects of religiosity could foster the internal strengths of adolescents. Specifically, adolescents who hold positive view and belief are able to be more committed in learning, have positive values and identity, and are socially competent. All these internal developmental assets can serve as valuable assets that assist adolescents in developing better life styles and cope with negative event and influences (Furrow et al., 2004; Greenfield \& Marks, 2007). The results of the study are further supported by previous studies (Hardy\& Walker, 2012; Walker \& Reimer, 2008; Milot \& Ludden, 2009; Yonker et al., 2012; Abdel-Khalek, 2009; Sallquist et al., 2010) which denoted that religiosity can promote better academic achievement, self-control, prosocial behaviour, life satisfaction, greater level of happiness and moral identity which continue to enhance well-being among adolescents. By highlighting that religion is crucial in promoting positive developmental assets amongst adolescents, intervention initiatives may consider and strengthen religion-based element.

A part of that, female adolescents scored significantly higher in both total and worldly aspect of Islamic worldview as compared to male adolescents. Similar findings also revealed by Furrow et al. (2004) who stated that female adolescents have more positive attitude toward religion especially in an earlier age. Results also denoted no significant gender differences between male and female adolescents in internal developmental assets. Precisely, female adolescents were found to have better commitment to learning and are socially competent as compared to male adolescents in the sub-dimension of internal developmental assets.

Regression analysis highlighted that religiosity personality was the only significant predictor of Malay adolescents' internal developmental assets. According to Hamzah et al. (2007), religiosity personality signifies the action or behaviour element of Islamic religiosity. This means that Malay adolescents who practice Islamic value have better internal assets. High score in the religiosity personality is an indication of personality that is guided by Islamic religious teachings. The results of the study on the relationship between Muslim religiosity and internal developmental assets is consistent with past findings in Western context which noted that participation in religion (Christian) activities contributes to adolescents' developmental assets (Roehlkepartain, 2003). Many studies (Atkiss, Moyer, Desai, \& Roland, 2011; Cotton, Zebracki, Rosenthal, Tsevat, \& Drotar, 2006) have addressed that in general, religion predicts adolescents' internal assets which in turn promotes positive development. Religious individuals behave in socially appropriate ways which in turn promote social competence among them (Sallquist et al., 2010).

In conclusion, this study evidenced the moderate to high level of Islamic religious belief and practices amongst Malay adolescents in Malaysia as measured by Muslim Religiosity Personality Inventory (MRPI) which was developed based on Quran and Sunnah - two primary sources of the Islamic law, belief and practice within 
(Sunni) Islam. Overall, Malay adolescents reported to have good internal developmental assets. In addition, female adolescents have higher commitment to learning, social competency and high Islamic worldview as compared to male adolescents. Furthermore, evident also highlighted the impact of Islamic worldview and personality on the internal developmental assets among Malay adolescents. Islamic religiosity personality contributed to adolescents' overall internal developmental assets. The results of the study provide better understanding regarding adolescents' religious belief and practices as well as its links to internal developmental assets amongst Malay adolescents in Malaysia.

\section{References}

Abdel-Khalek, A. M. (2009). Religiosity, subjective well-being, and depression in Saudi children and adolescents. Mental Health, Religion and Culture, 12(8), 803-815. http://dx.doi.org/10.1080/1367467090 3006755

Annalakshmi, N., \& Abeer, M. (2011). Islamic worldview, religious personality and resilience among Muslim adolescent students in India. Europe's Journal of Psychology, 7(4), 716-738. http://dx.doi.org/10.5964/ejop. v7i4.161

Argyle, M. (2002). State of the art: Religion. Psychologist, 15(1), 22-26.

Atkiss, K., Moyer, M., Desai, M., \& Roland, M. (2011). Positive youth development: An integration of the Developmental Assets Theory and the Socio-Ecological Model. American Journal of Health Education, 42(3), 171-180. http://dx.doi.org/10.1080/19325037.2011.10599184

Ball, J., Armstead, L., \& Austin, B. J. (2003). The relationship between religiosity and adjustment among African-American, female, urban adolescents. Journal of Adolescence, 26, 431-446. http://dx.doi.org/10.1016/S0140-1971(03)00037-X

Benson, P. L., Scales, P. C., Leffert, N., \& Roehlkepartain, E. C. (1999). A fragile foundation: The state of developmental assets among American Youth. Minneapolis, MN: Search Institute.

Cotton, S., Zebracki, K., Rosenthal, S. L., Tsevat, J., \& Drotar, D. (2006). Religion/spirituality and adolescent health outcomes: A review. Journal of Adolescent Health, 38, 472-480. http://dx.doi.org/10.1016/j. jadohealth.2005.10.005

French, D. C., Eisenberg, N., Vaughan, J., Purwono, U., \& Suryanti, T. A. (2008). Religious involvement and the social competence and adjustment of Indonesian Muslim adolescents. Developmental Psychology, 44, 597-611. http://dx.doi.org/10.1037/0012-1649.44.2.597

French, D. C., Purwono, U., \& Triwahyuni, A. (2011). Friendship and the religiosity of Indonesian Muslim adolescents. Journal of Youth and Adolescence, 40, 1623-1633. http://dx.doi.org/10.1007/s10964-0119645-7

Furrow, J. L., King, P. E., \& White, K. (2004). Religion and positive youth development: Identity, meaning, and prosocial concerns. Applied Developmental Science, 8, 17-26. http://dx.doi.org/10.1207/S1532480X ADS0801_3

Greenfield, E. A., \& Marks, N. F. (2007). Religious social identity as an explanatory factor for associations between more frequent formal religious participation and psychological well-being. The International Journal for the Psychology of Religion, 17, 245-259. http://dx.doi.org/10.1080/10508610701402309

Hamzah, A., Krauss, S. E., Noah, S. M., Suandi, T., Juhari, R., Manap, J., Mastor, K. A., ... Kassan, H. (2007). Muslim Religiosity and Personality Assessment: Prototype for Nation Building. Institute for Social Science Studies (IPSAS), Universiti Putra Malaysia.

Hardy, S. A., \& Carlo, G. (2005). Identity as a source of moral motivation. Human Development, 48, 232-256. http://dx.doi.org/10.1159/000086859

Hardy, S. A., \& Walker, L. J. (2012). Religiosity and adolescent empathy and aggression: The mediating role of moral identity. Psychology of Religion and Spirituality, 4(3), 237-248. http://dx.doi.org/10.1037/a0027566

Hart, D., \& Atkins, R. (2004). Religious participation and the development of moral identity in adolescence. In T. A. Thorkildsen, \& H. J. Walberg (Eds.), Nurturing morality (pp. 157-172). New York, NY: Kluwer Academic/Plenum. http://dx.doi.org/10.1007/978-1-4757-4163-6_9

King, P. E. (2003). Religion and identity: The role of ideological, social, and spiritual contexts. Applied Developmental Science, 7, 197-204. http://dx.doi.org/10.1207/S1532480XADS0703_11 
Krauss, S. E., Hamzah, A. H., Suandi, T., Noah, S. M., Juhari, R., Manap, J. H. (2006). Exploring regional differences in religiosity among Muslim youth in Malaysia. Review of Religious Research, 47, 238-252.

Lerner, R. M. (2004). Liberty: Thriving and civic engagement among America's youth. Thousand Oaks, CA: Sage.

Milot, A. S., \& Ludden, A. B. (2009). The effects of religion and gender on well-being, substance use, and academic engagement among rural adolescents. Youth \& Society, 40, 403-425. http://dx.doi.org/10.1177/ 0044118 X08316668

Nor Ba'yah, A. K., Samsudi, A. R., Mimi Hanida, A. M., Wan Amizah, W. M., Chong, S. T., \& Nasrudin, S. (2012). Development of self-report measure of assessing developmental assets among at-risk youth in Malaysia. Child Adolescence and Social Work Journal, 29(5), 391-407. http://dx.doi.org/10.1007/s10560012-0267-z

Ortega, A., \& Krauss, S. E. (2013). Religiosity among Muslim adolescents according to gender and school type. Pertanika Journal of Social Sciences and Humanities, 21(8), 139-146.

Petts, R. J. (2009). Trajectories of religious participation from adolescence to young adulthood. Journal for the Scientific Study of Religion, 48, 552-571. http://dx.doi.org/10.1111/j.1468-5906.2009.01465.x

Regnerus, M. D., Smith, C., \& Smith, B. (2004). Social context in the development of adolescent religiosity. Applied Developmental Science, 8, 27-38. http://dx.doi.org/10.1207/S1532480XADS0801_4

Roehlkepartain, E. (2003). Engaging families in service: Rationale and resources for congregations. Family Ministry: Empowering Through Faith, 17(3), 22-41.

Scales, P. C., Mannes, M., \& Sema, A. Jr. (2006). Positive adaptation, resilience and the developmental assets framework. Mineopolis, MN: Search Institute.

Scales, P. C., \& Benson, P. L. (2006). Toword quality and equality. Fullfilling our promises to America's children and youth. Search Institute Insights \& Evidence, 3, 1-10.

Schwartz, K. D., Bukowski, W. B., \& Aoki, W. T. (2006). Mentors, friends, and gurus: Peer and nonparent influences on spiritual development. In E. C. Roehl Kepartain, P. E. King, L. Wagner, \& P. L. Benson (Eds.), The handbook of spiritual development in childhood and adolescence (pp. 310-323). Thousand Oaks, CA: Sage Publication. http://dx.doi.org/10.4135/9781412976657.n22

Search institute. (2005). Developmental assets profile; User Manual. Minneapolis, MN: Search Institute.

Search Institute. (2004). Tapping the power of community: Building assets to strengthen substance abuse prevention. Search Institute, Insights \& Evidence, 2(1), 1-14.

Search Institute. (2008). Developmental assets: A profile of your youth. Minneapolis, MN: Search Institute.

Sallquist, J., Eisenberg, N., French, D. C., Purwono, U., \& Suryanti, T. A. (2010). Indonesian adolescents' spiritual and religious experiences and their longitudinal relations with socioemotional functioning. Developmental Psychology, 46(3), 699-716. http://dx.doi.org/10.1037/a0018879

Walker, L. J., \& Reimer, K. S. (2006). The relationship between moral and spiritual development. In E. C. Roehlkepartain, P. E. King, L. Wagener, \& P. L. Benson (Eds.), The handbook of spiritual development in childhood and adolescence (pp. 224-238). Thousand Oaks, CA: Sage. http://dx.doi.org/10.4135/ 9781412976657.n16

Wilcox, W., Bradford, M. C., \& Franz, D. (2004). Focused on the family? Religious traditions, family discourse, and pastoral practice. Journal for the Scientific Study of Religion, 43(4), 491-504. http://dx.doi.org/10.1111/j.1468-5906.2004.00251.x

Yonker, J. E., Schnabelrauch, C. A., \& DeHaan, L. G. (2012). The relationship between spirituality and religiosity on psychological outcomes in adolescents and emerging adults: A meta-analytic review. Journal of Adolescence, 35, 299-314. http://dx.doi.org/10.1016/j.adolescence.2011.08.010

\section{Copyrights}

Copyright for this article is retained by the author(s), with first publication rights granted to the journal.

This is an open-access article distributed under the terms and conditions of the Creative Commons Attribution license (http://creativecommons.org/licenses/by/3.0/). 